\section{Economics of Utilizing Alternative Containers in Ornamental Crop Production Systems}

\author{
Robin G. Brumfield ${ }^{1}$, Alyssa J. DeVincentis ${ }^{1}$, Xueni Wang ${ }^{2}$, \\ R. Thomas Fernandez ${ }^{2}$, Susmitha Nambuthiri ${ }^{3}$, Robert L. Geneve ${ }^{3}$, \\ Andrew K. Koeser ${ }^{4}$, Guihong $\mathrm{Bi}^{5}$, Tongyin $\mathrm{Li}^{5}$, Youping Sun ${ }^{6}$, \\ Genhua Niu ${ }^{6}$, Diana Cochran ${ }^{7}$, Amy Fulcher $^{8}$, and J. Ryan Stewart ${ }^{9}$
}

ADDITIONAL INDEX WORDS. cost of production, alternative containers, biocontainers, wood pulp, keratin, coir, fabric container

Summary. As high-input systems, plant production facilities for liner and container plants use large quantities of water, fertilizers, chemical pesticides, plastics, and labor. The use of renewable and biodegradable inputs for growing aesthetically pleasing and healthy plants could potentially improve the economic, environmental, and social sustainability of current production systems. However, costs for production components to integrate sustainable practices into established systems have not been fully explored to date. Our objectives were to determine the economic costs of commercial production systems using alternative containers in aboveground nursery systems. We determined the cost of production (COP) budgets for two woody plant species grown in several locations across the United States. Plants were grown in plastic pots and various alternative pots made from wood pulp (WP), fabric (FB), keratin (KT), and coconut fiber (coir). Cost of production inputs for aboveground nursery systems included the plant itself (liner), liner shipping costs, pot, pot shipping costs, substrate, substrate shipping costs, municipal water, and labor. Our results show that the main difference in the COP is the price of the pot. Although alternative containers could potentially increase water demands, water is currently an insignificant cost in relation to the entire production process. Use of alternative containers could reduce the carbon, water, and chemical footprints of nurseries and greenhouses; however, the cost of alternative containers must become more competitive with plastic to make them an acceptable routine choice for commercial growers.

$\mathrm{T}$ he green industry, also known as environmental horticulture, refers to a wide variety of suppliers, producers, distributors, installers, firms, and businesses involved in horticulture in the United States. It is usually divided into nursery and floriculture crops and is the number one agricultural commodity in five northeastern U.S. states. Nationally, the number of producers continues to decline and profit margins are typically low, leaving little room for growers to absorb significant increases in costs or decreases in revenues. Unlike farmers who produce field crops, nursery and greenhouse firms bear the entire price, market, and production risks because these crops have had no government support programs (Brumfield, 2010). The importance of knowing carbon emissions from the green industry is escalating as climate change data continue to emerge. Such emission could come from a variety of sources related to horticultural production including nurseries, greenhouses, wholesale distribution firms, transportation, landscape and design services, and retail operations (Hall, 2010). In addition, efforts are underway to reduce the use of petroleum-based inputs in crop production systems because of the high waste streams involved. Growers will have an incentive to conserve resources in the future to ensure the longevity of their operations. Promoting environmental sustainability throughout their operations may also be crucial in maintaining a customer base that is increasingly aware of environmental issues (Hall et al., 2010). Additionally, researchers have found that consumers in the midwestern United States are willing to pay more for plants that were produced in biodegradable, compostable, or recyclable pots (Yue et al., 2011).

A reduction of certain inputs could reduce the environmental impacts of horticultural businesses. One such resource is plastic, used for a variety of purposes in ornamental crop production systems including propagation, production, packaging, transportation, as a marketing vehicle, and as a covering for production structures. For example, recent research found that $16 \%$ of the carbon dioxide $\left(\mathrm{CO}_{2}\right)$ emissions of petunia (Petunia $\times$ hybrida) production are linked to the traditional plastic containers used to grow the plants (Koeser et al., 2014). Both the manufacturing and disposal of agricultural plastics exhibit large environmental burdens. Plastics used in agricultural practices are challenging to recycle due to contamination problems or ultraviolet light degradation (Hall et al., 2010). Consequently, replacing plastic pots with alternative materials can reduce the environmental impact of crop production (Garthe and Kowal, 1993).

The available alternative containers are made from a variety of animal and plant materials, including feathers, manure, rice hulls, and straw. Some decompose quickly and are biodegradable, often referred to as biocontainers (Nambuthiri et al., 2015). Using alternative containers increases the sustainability of an operation by reducing reliance on petroleum and minimizing disposal issues. Alternative containers, except the one made from recycled plastic-fiber mix, have greater compression strength than plastic containers although they may not be "compostable" by ASTM standards (Wang, 2013). This characteristic would decrease landfill space and supports other research citing that alternative containers decompose more quickly than traditional plastic (Candido et al., 2008; Evans and Karcher, 2004).

Research to date suggests that alternative containers can produce

\begin{tabular}{llll}
\hline $\begin{array}{l}\text { Units } \\
\text { To convert U.S. to SI, } \\
\text { multiply by }\end{array}$ & U.S. unit & SI unit & $\begin{array}{l}\text { To convert SI to U.S., } \\
\text { multiply by }\end{array}$ \\
\hline 0.4047 & acre(s) & ha & 2.4711 \\
3.7854 & gal & $\mathrm{L}$ & 0.2642 \\
2.54 & inch(es) & $\mathrm{cm}$ & 0.3937 \\
1.6093 & mile(s) & $\mathrm{km}$ & 0.6214 \\
0.7646 & yard & $\mathrm{m}^{3}$ & 1.3080
\end{tabular}


plants with similar or better performance than plants grown in plastic containers in the greenhouse when water supply is sufficient (Evans and Hensley, 2004; Lopez and Camberato, 2011; Nambuthiri and Ingram, 2014). However, the durability of alternative containers can be an issue for certain crops with production times longer than 1 year (Li et al., 2015).

If alternative containers are acceptable substitutes for traditional plastic containers from a production standpoint, it is necessary to look at the use of alternative containers from an economic perspective to encourage their use. Specifically, useful information could be gleaned from a comparison of the costs associated with alternative containers relative to that of industrystandard plastic containers.

This study translates horticultural production data into a cost analysis applicable to commercial nursery and greenhouse operations. We estimated the COP for two types of ornamental crops grown in four types of biodegradable containers in aboveground nursery systems. These COP budgets are a useful tool for growers in that they provide an information

This research was partially funded by the USDA Specialty
Crops Research Initiative Grant number $2010-01190$
with matching resources from Rutgers, the State Univer-
sity of New Jersey. This project was supported by the
USDA National Institute of Food and Agriculture, Hatch
project numbers NJ02278, KY011032, MICL02010,
TEX09045, TEN00406, MIS211090.

The authors appreciate assistance from Spring Meadow Nursery, Inc., Renewed Earth, Inc., Griffin Greenhouse Supplies, Western Pulp Products, Urban Farmer, and Myers Lawn and Garden and A.J. Both, Gal Hochman, and Paul Gottlieb.

${ }^{1}$ Department of Agricultural, Food, and Resource Economics, Rutgers, The State University of New Jersey, 55 Dudley Road, New Brunswick, NJ 08901

${ }^{2}$ Department of Horticulture, Michigan State University, 1066 Bogue Street, Room A216, East Lansing, MI 48824

${ }^{3}$ Department of Horticulture, University of Kentucky, Lexington, KY 40546

${ }^{4}$ Department of Environmental Horticulture, Center For Landscape Conservation and Ecology, IFAS, University of Florida-Gulf Coast Research and Education Center, 14625 County Road 672, Wimauma, FL 33598

${ }^{5}$ Department of Plant and Soil Sciences, Mississippi State University, Mississippi State, MS 39762

${ }^{6}$ Texas A\&M AgriLife Research and Extension Center at El Paso, Texas A\&M University, 1380 A\&M Circle, El Paso, TX 79927

${ }^{7}$ Department of Horticulture, Iowa State University, 106 Horticulture Hall, Ames, IA 50011

${ }^{8}$ Department of Plant Sciences, University of Tennessee, Knoxville, TN 37996

${ }^{9}$ Department of Plant and Wildlife Sciences, Brigham Young University, Provo, UT 84602

${ }^{10}$ Corresponding author. E-mail: brumfield@aesop. rutgers.edu. base to assist with choices involving risk, crop selection, type of inputs, expansion, and pricing (Hinson et al., 2007).

\section{Materials and methods}

We collected data from researchers at Michigan State University, University of Kentucky, University of Tennessee, Mississippi State University, and Texas A\&M University who grew 'Green Velvet' boxwood (Buxus sempervirens $\times B$. microphylla var. koreana) and 'Dark Knight' bluebeard (Caryopteris $\times$ clandonensis) in aboveground nursery conditions.

Several criteria were used to decide on the choice of plants: to select species that would grow over the large variation in climates seen in Michigan, Kentucky, Texas, and Mississippi; to select plants that would normally be grown in a l-gal container; to select a plant that in 1 year would be a standard nursery shrub with moderate irrigation requirements followed by a woody perennial with a higher irrigation requirement. Researchers in each state recorded the details of labor inputs for production of plants in the experiments using alternative containers from 2011 to 2013. They used black plastic and four alternative containers: WP, FB, $\mathrm{KT}$, and coir (Table 1). We also reviewed experimental results from several of the participating researchers to summarize nonlabor inputs, such as water use, substrate price, substrate shipping, plants, and pots. All of this information was summarized to produce COP budgets for the plants.

An estimate of 21,000 pots per acre was used to determine per acre cost (Halcomb and Fare, 2009). Many of the COP assumptions and format are similar to the "enterprise budget for ornamental crops in plant hardiness zones 8 and 9" created by Louisiana State University (Hinson et al., 2007). Our budgets summarize the work of horticultural researchers and may not include the entire scope of activities and associated inputs necessary in commercial operations.

The experimental procedure is outlined in Wang et al. (2015). Our analysis includes data from 2012 and 2013, but excludes 2011 data due to high mortality from a disease issue in Mississippi, Texas, and Kentucky. Researchers grew 'Green Velvet' boxwood in 2012 and 'Dark Knight' bluebeard in 2013 using a one-factor completely randomized design to test different container types with three replicates of 15 plants each (Wang et al., 2015). Guard plants surrounded all experimental plots to minimize edge effects.

We analyzed eight key inputs that represent the general nursery production: the liner, liner shipping, pot, pot shipping, substrate, substrate shipping, municipal water, and labor. We combined these inputs to determine the COP budgets for both crops. Table 2 shows an example of a COP budget using plastic pots. This

Table 1. Summary of prices of alternative containers used to grow 'Green Velvet' boxwood and 'Dark Knight' bluebeard in above-ground nursery conditions in Michigan, Kentucky, Tennessee, Mississippi, and Texas.

\begin{tabular}{|c|c|c|c|}
\hline Container $^{\mathrm{z}}$ & $\begin{array}{c}\text { Volume } \\
(\mathrm{L})^{\mathrm{y}}\end{array}$ & Model & Price per pot \\
\hline Black plastic $^{\mathrm{x}, \mathrm{w}}$ & 3.8 & Polyethylene PF 400-SM & $\$ 0.40$ \\
\hline Wood pulp ${ }^{\mathrm{x}, \mathrm{w}}$ & 3.9 & Wood pulp 7X7RD & $\$ 0.62$ \\
\hline Kord fiberv & 3.9 & $\begin{array}{l}\text { Kord 07.50 Fiber Grow } \\
\text { Nursery Pot }\end{array}$ & $\$ 0.69$ \\
\hline Fabric $^{\mathrm{x}}$ & 3.4 & Root Pouch 15-20 mo. & $\$ 0.44$ \\
\hline Keratin $^{\mathrm{x}}$ & 3.0 & Keratin Container & Not available on the market \\
\hline Coir fiber ${ }^{\mathrm{w}, \mathrm{u}}$ & 3.8 & $\begin{array}{l}3174 \text { Quickstart } 8 \text { "Retail } \\
\text { Nursery Pot }\end{array}$ & $\begin{array}{l}\text { Only produced as part } \\
\text { of a national program } \\
\text { and have not yet been } \\
\text { sold commercially }\end{array}$ \\
\hline
\end{tabular}

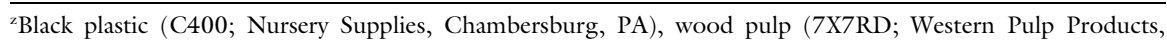
Corvallis, OR), keratin (Horticultural Research Institute, Washington, DC), fabric [Root Pouch, Hillsboro, OR (based on recycled plastic)], coir fiber (Retail Nursery Pot, Markham, ON, Canada).

${ }^{\mathrm{y}} \mathrm{l}$ gal $=3.7854 \mathrm{~L}$.

'Used to grow 'Green Velvet' boxwood (Buxus sempervirens $\times$ B. microphylla var. koreana).

"Used to grow 'Dark Knight' bluebeard (Caryopteris $\times$ clandonensis).

'Used to grow river birch (Betula nigra).

"l 1 inch $=2.54 \mathrm{~cm}$. 
technique was replicated for WP, FB container, $\mathrm{KT}$, and coir pots in Tables $3-6$, respectively.

Liner costs were taken from the 2013-14 price list at Spring Meadow Nursery in Grand Haven, MI, who donated the plants. For consistency, plants in all locations were from this nursery. The prices were $\$ 2.06$ per plant for 'Green Velvet' boxwood and \$2.17 per plant for 'Dark Knight' bluebeard. We added an additional $15 \%$ to the original price to account for the cost of shipping 4 -inch liners.

Container details and their prices are summarized in Table 1. Prices for KT and coir pots could not be determined because they are not yet commercially available. The plant budgets in Table 7 include a sensitivity analysis using the prices of $\$ 0.50$, $\$ 1.00$, or $\$ 2.00$ for $\mathrm{KT}$ and coir pots to cover a conservative spectrum of price possibilities. Container shipping costs were estimated to be a flat rate of
$\$ 250 /$ acre based on information from an industry supplier.

Estimates for substrate shipment were determined for several lengths of a delivery that was completed in a single day: 10, 50, 100, and 200 miles. Substrate shipment costs were estimated based on the freight costs from the growing media supplier. Three factors determine the shipping cost of a high volume load $\left(140 \operatorname{yard}^{3}\right)$, a flat fee of $\$ 50.00$ ( $\$ 5.00$ per mile traveled), and a $10 \%$ fuel surcharge. The cost of filling a container with substrate consisting of $85 \%$ pine bark and $15 \%$ peatmoss was estimated using the cost of $\$ 38.60 / \mathrm{yard}^{3}$.

The costs of water and labor were determined separately for each state. The quantity of daily water use through overhead irrigation was determined by Wang et al. (2015), varied by location and container type, and was calculated based on a 150-d growing season. The cost of watering each pot was determined from the daily water use and price of municipal water per 200 gal in cities adjacent to each research location (Circle of Blue, 2014). Although most nurseries do not use municipal water, it is a useful overestimation in this study because the irrigation costs prove to be insignificant in the budgets.

Additionally, a sensitivity analysis was performed to see how potentially high costs of municipal water would increase production costs. A price of $\$ 0.005 / \mathrm{gal}$ was used as a base price because it is slightly higher than the average prices in our research areas (Circle of Blue, 2014). The analysis compares potential changes in irrigation cost based on the doubling and quadrupling of that price to predict potential production costs as water becomes more expensive in the future.

Labor data collected were inconsistent and inconclusive. Based on

Table 2. Input costs for total cost of production (COP), cost per plant, cost per acre, and proportion of average COP for 'Green Velvet' boxwood and 'Dark Knight' bluebeard grown in plastic pots in Michigan (MI), Kentucky (KY), Tennessee (TN), Mississippi (MS), and Texas (TX).

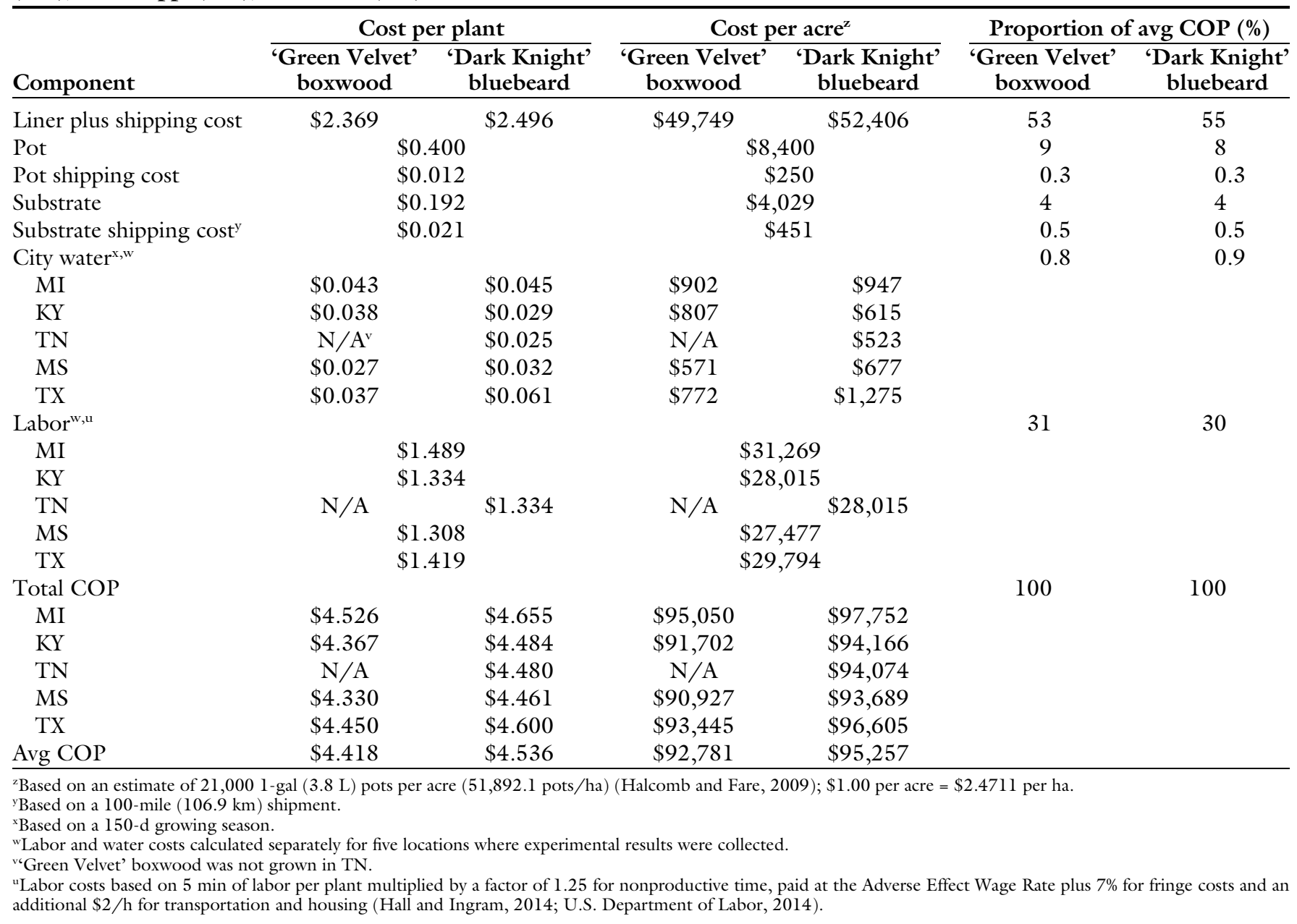


Table 3. Input costs for total cost of production (COP), cost per plant, cost per acre, and proportion of average COP for 'Green Velvet' boxwood and 'Dark Knight' bluebeard grown in wood pulp pots in Michigan (MI), Kentucky (KY), Tennessee (TN), Mississippi (MS), and Texas (TX).

\begin{tabular}{|c|c|c|c|c|c|c|}
\hline \multirow[b]{2}{*}{ Component } & \multicolumn{2}{|c|}{ Cost per plant } & \multicolumn{2}{|c|}{ Cost per acre } & \multicolumn{2}{|c|}{ Proportion of avg COP (\%) } \\
\hline & $\begin{array}{l}\text { 'Green Velvet' } \\
\text { boxwood }\end{array}$ & $\begin{array}{c}\text { 'Dark Knight' } \\
\text { bluebeard }\end{array}$ & $\begin{array}{l}\text { 'Green Velvet' } \\
\text { boxwood }\end{array}$ & $\begin{array}{c}\text { 'Dark Knight' } \\
\text { bluebeard }\end{array}$ & $\begin{array}{l}\text { 'Green Velvet' } \\
\text { boxwood }\end{array}$ & $\begin{array}{c}\text { 'Dark Knight' } \\
\text { bluebeard }\end{array}$ \\
\hline Pot & \multicolumn{2}{|c|}{$\$ 0.620$} & \multicolumn{2}{|c|}{$\$ 13,020$} & 13 & 13 \\
\hline Pot shipping cost & \multicolumn{2}{|c|}{$\$ 0.012$} & \multicolumn{2}{|c|}{$\$ 250$} & $0.3 \%$ & $0.2 \%$ \\
\hline Substrate & \multicolumn{2}{|c|}{$\$ 0.197$} & \multicolumn{2}{|c|}{$\$ 4,135$} & 4 & 4 \\
\hline MI & $\$ 0.031$ & $\$ 0.032$ & $\$ 658$ & $\$ 668$ & & \\
\hline KY & $\$ 0.042$ & $\$ 0.036$ & $\$ 880$ & $\$ 747$ & & \\
\hline $\mathrm{TN}$ & $\mathrm{N} / \mathrm{A}^{\mathrm{v}}$ & $\$ 0.029$ & $\mathrm{~N} / \mathrm{A}$ & $\$ 606$ & & \\
\hline MS & $\$ 0.034$ & $\$ 0.037$ & $\$ 710$ & $\$ 775$ & & \\
\hline TX & $\$ 0.048$ & $\$ 0.071$ & $\$ 1,006$ & $\$ 1,482$ & & \\
\hline Labor $^{\mathrm{w}, \mathrm{u}}$ & \multicolumn{2}{|c|}{$\$ 1.489$} & & & 30 & 29 \\
\hline MS & \multicolumn{2}{|c|}{$\$ 1.308$} & \multicolumn{2}{|c|}{$\$ 27,477$} & & \\
\hline TX & \multicolumn{2}{|c|}{$\$ 1.419$} & \multicolumn{2}{|c|}{$\$ 29,794$} & & \\
\hline Total COP & & & & & 100 & 100 \\
\hline MI & $\$ 4.740$ & $\$ 4.867$ & $\$ 99,543$ & $\$ 102,210$ & & \\
\hline $\mathrm{KY}$ & $\$ 4.596$ & $\$ 4.716$ & $\$ 96,512$ & $\$ 99,036$ & & \\
\hline $\mathrm{TN}$ & $\mathrm{N} / \mathrm{A}$ & $\$ 4.709$ & $\mathrm{~N} / \mathrm{A}$ & $\$ 98,894$ & & \\
\hline MS & $\$ 4.562$ & $\$ 4.692$ & $\$ 95,803$ & $\$ 98,525$ & & \\
\hline TX & $\$ 4.687$ & $\$ 4.836$ & $\$ 98,417$ & $\$ 101,550$ & & \\
\hline Avg COP & $\$ 4.646$ & $\$ 4.764$ & $\$ 97,569$ & $\$ 100,043$ & & \\
\hline
\end{tabular}

${ }^{2}$ Based on an estimate of 21,000 l-gal $(3.8 \mathrm{~L})$ pots per acre $(51,892.1$ pots $/$ ha $)($ Halcomb and Fare, 2009); $\$ 1.00$ per acre $=\$ 2.4711$ per ha.

${ }^{y}$ Based on a 100 -mile $(106.9 \mathrm{~km})$ shipment.

${ }^{x}$ Based on a 150 -d growing season.

"Labor and water costs calculated separately for five locations where experimental results were collected.

"Green Velvet' boxwood was not grown in TN.

"Labor costs based on 5 min of labor per plant multiplied by a factor of 1.25 for nonproductive time, paid at the Adverse Effect Wage Rate plus $7 \%$ for fringe costs and an additional \$2 per h for transportation and housing (Hall and Ingram, 2014; U.S. Department of Labor, 2014).

detailed information from Michigan State University, the average labor per plant was estimated to be $5 \mathrm{~min}$ for potting, weeding, harvesting, and general oversight. This is higher than the $\approx 2$ min per pot estimated by Hinson et al. (2007) for azalea (Rhododendron sp.) grown at 30,000 pots/acre and is lower than the 6-12 min per plant for data collected from Kentucky. However, the labor data from Kentucky included time that was involved in research evaluation and irrigation setup that would not be part of a typical production nursery. The time was multiplied by a factor of 1.25 to account for non-productive time such as set-up, cleanup, etc. (Hall and Ingram, 2014). Labor costs were estimated using the Adverse Effect Wage Rate from 2014 for each state, which is the wage level that must be offered and paid to U.S. and alien workers by agricultural employers of nonimmigrant $\mathrm{H}-2 \mathrm{~A}$ agricultural workers (Hall and Ingram, 2014; U.S. Department of Labor, 2014). An estimate of $7 \%$ for fringe costs was included for worker's compensation insurance and state payroll taxes $(6 \%$ and $1 \%$ respectively) plus $\$ 2$ per hour for housing and transportation expenses. These costs were determined based on advice from a New Jersey nursery, but could vary significantly between businesses and locations.

Selling, delivering, and office and administrative costs were assumed to be the same for production in the various containers and were not included in the COP budgets.

\section{Results and discussion}

Detailed COP budgets for plastic, $\mathrm{WP}, \mathrm{FB}, \mathrm{KT}$, and coir pots are shown in Tables 2-6. The average COP budgets and a price sensitivity analysis for KT and coir pots are summarized in Table 7 . In our analyses, plastic pots were always the least expensive production containers. However, there will likely be costs to the environment through landfill use and carbon emissions and we were not able to quantify these externalities in our analyses.

Based on these data, FB pots have potential to be a cost-effective alternative to plastic pots for growing 'Green Velvet' boxwood without affecting the profit margins. However, Green Velvet plants grown in FB pots showed reduced growth in some locations, most likely negatively impacted by smaller substrate volume and possibly water stress (Wang et al., 2015).

KT may also be a cost-effective substitute for plastic if containers can be purchased at a similar price point to plastic pots (less than $\$ 0.50$ ) when it becomes available. This is consistent with concurrent research that found similarities between plastic and KT, specifically their rigid, nonporous walls 
Table 4. Input costs for total cost of production (COP), cost per plant, cost per acre, and proportion of average COP for 'Green Velvet' boxwood grown in fabric container pots in: Michigan (MI), Kentucky (KY), Tennessee (TN), Mississippi (MS), and Texas (TX).

\begin{tabular}{lccc}
\hline Component & Cost per plant & Cost per acre $^{\mathrm{z}}$ & $\begin{array}{c}\text { Proportion } \\
\text { of avg COP (\%) }^{\text {Por }}\end{array}$ \\
\hline Liner plus shipping cost & $\$ 2.369$ & $\$ 49,749$ & 53 \\
Pot & $\$ 0.440$ & $\$ 9,240$ & 10 \\
Pot shipping cost & $\$ 0.012$ & $\$ 250$ & 0.3 \\
Substrate & $\$ 0.172$ & $\$ 3,605$ & 4 \\
Substrate shipping cost ${ }^{\mathrm{y}}$ & $\$ 0.019$ & $\$ 404$ & 0.4 \\
City water ${ }^{\mathrm{x}, \mathrm{w}}$ & & & \\
MI & $\$ 0.028$ & $\$ 587$ & \\
KY & $\$ 0.045$ & $\$ 951$ & \\
MS & $\$ 0.030$ & $\$ 638$ & \\
TX & $\$ 0.034$ & $\$ 705$ & \\
Labor & & & \\
MI & $\$ 1.489$ & $\$ 31,269$ & \\
KY & $\$ 1.334$ & $\$ 28,015$ & \\
MS & $\$ 1.308$ & $\$ 27,477$ & \\
TX & $\$ 1.419$ & $\$ 29,794$ & \\
Total COP & & & \\
MI & $\$ 4.529$ & $\$ 95,103$ & \\
KY & $\$ 4.391$ & $\$ 92,214$ & \\
MS & $\$ 4.351$ & $\$ 91,363$ & \\
TX & $\$ 4.464$ & $\$ 93,747$ & \\
Avg COP & $\$ 4.434$ & $\$ 93,107$ & \\
\hline
\end{tabular}

${ }^{z}$ Based on an estimate of $21,000 \mathrm{l}$-gal $(3.8 \mathrm{~L})$ pots per acre $(51,892.1$ pots $/$ ha $)($ Halcomb and Fare, 2009); $\$ 1.00$ per acre $=\$ 2.4711$ per ha.

yBased on a 100 -mile $(106.9 \mathrm{~km})$ shipment.

xBased on a 150 -d growing season.

"Labor and water costs calculated separately for five locations where experimental results were collected.

'Labor costs based on 5 min of labor per plant multiplied by a factor of 1.25 for nonproductive time, paid at the Adverse Effect Wage Rate plus 7\% for fringe costs and an additional $\$ 2 / \mathrm{h}$ for transportation and housing (Hall and Ingram, 2014; U.S. Department of Labor, 2014).

(Nambuthiri et al., 2015). For growing 'Dark Knight' bluebeard, the cost to produce in coir containers was the most expensive based on conservative price projections (Table 6). Coir containers large enough for nursery production $(\geq \mathrm{l}$ gal) are not currently commercially available. Based on prices for smaller containers, a range of COPs were calculated (Table 7). Using \$1.00 per unit, coir containers made up a much larger percent $(20 \%)$ of the COP budget than a plastic pot $(9 \%)$ (Table 6). The price of a pot is a substantial input to both of these budgets. Coir is an attractive alternative material for nursery containers. It is manufactured from a renewable bioproduct and breaks down readily under composting conditions. Environmentally conscious consumers are willing to pay a premium for plants grown in nonplastic or recyclable containers (Khachatryan et al., 2014). Studies have indicated that depending on the degree of biodegradability, consumers are willing to spend an additional $\$ 0.15$ and $\$ 0.23$ per plant
(Yue et al., 2010). For coir containers to be competitive, the cost per container must be priced within $\$ 0.25$ or less per container of current plastic container prices.

For both plant species, nursery production with WP pots was more costly than with traditional plastic pots. This is due to their higher cost per pot and slightly larger size, requiring larger amounts of substrate per pot. It is important to note that these pots are only available in limited sizes, which could affect their ability to be easily integrated into production systems. Although WP pots were associated with more water use compared with plants grown in plastic pots, they were the alternative container most comparable to plastic based on plant growth and durability (Wang, 2013).

Using KT and FB pots could reduce production costs for 'Green Velvet' boxwood under specific circumstances. Because there were no significant difference in plant growth index between alternative containers in all states and years, it can be assumed that container type had no influence on plant performance (Wang et al., 2015). If the containers were purchased at the same price, using KT and FB pots to grow 'Green Velvet' boxwood could reduce production costs to growers because of their smaller size compared with plastic and WP containers. This would be true for other containers if they were smaller than plastic, but as they are currently produced, KT and FB containers are the only types of containers that are smaller than plastic. Smaller containers require less substrate volume and therefore reduced costs for substrate and shipping of substrate. A sensitivity analysis for various shipping distances for substrate can be seen in Table 8. Using FB containers instead of plastic could reduce costs by between $\$ 433$ and $\$ 515$ per acre depending on shipping distance. However, accounting for the $\$ 0.04$ difference in price per pot between $\mathrm{FB}$ and plastic, producing plants in plastic pots costs $\$ 400$ less per acre than using FB pots even after accounting for the additional substrate required to produce in plastic pots. Using KT instead of plastic could save between $\$ 865$ and \$1029 per acre depending on shipping distance for the substrate. However, the price of KT pots needs to only be $\$ 0.05$ higher per pot than plastic pots to outweigh these potential savings.

Wood pulp pots require more substrate than do plastic pots and could cost an extra $\$ 108$ to $\$ 129$ per acre depending on shipping distance of substrate. In addition to the added substrate required, WP pots cost $\$ 0.12$ more per unit than plastic pots, making them an expensive option.

Coir pots are the exact same size as plastic and require the same amount of substrate. This makes them a feasible substitute to grow 'Dark Knight' bluebeard if cost to the grower was the same for all pots. However, to date, coir pots have not been commercially available at a competitive price.

Based on recent municipal water prices, the cost of additional irrigation needed for alternative containers was determined to not be a concern. The cost of municipal water for irrigation was never more than $1.0 \%$ of any plant budget. This small fraction can be seen in the percentage column of Tables 2-6 and in Figs. 1 and 2. 
Table 5. Input costs for total cost of production (COP), cost per plant, cost per acre, and proportion of average COP for 'Green Velvet' boxwood grown in keratin pots in Michigan (MI), Kentucky (KY), Mississippi (MS), and Texas (TX).

\begin{tabular}{lccc}
\hline Component & Cost per plant & Cost per acre & $\begin{array}{c}\text { Proportion of } \\
\text { avg COP (\%) }\end{array}$ \\
\hline Liner plus shipping cost & $\$ 2.369$ & $\$ 49,749$ & 48 \\
Pot & $\$ 1.000$ & $\$ 21,000$ & 20 \\
Pot shipping cost & $\$ 0.012$ & $\$ 250$ & 0.2 \\
Substrate & $\$ 0.151$ & $\$ 3,181$ & 3 \\
Substrate shipping cost ${ }^{\mathrm{y}}$ & $\$ 0.017$ & $\$ 356$ & 0.3 \\
City water,w & & & \\
MI & $\$ 0.023$ & $\$ 490$ & \\
KY & $\$ 0.037$ & $\$ 773$ & \\
MS & $\$ 0.020$ & $\$ 418$ & \\
TX & $\$ 0.028$ & $\$ 598$ & \\
Labor & & & \\
MI & $\$ 1.489$ & $\$ 31,269$ & \\
KY & $\$ 1.334$ & $\$ 28,015$ & \\
MS & $\$ 1.308$ & $\$ 27,477$ & \\
TX & $\$ 1.419$ & $\$ 29,794$ & \\
Total COP & & & \\
MI & $\$ 5.062$ & $\$ 106,294$ & \\
KY & $\$ 4.920$ & $\$ 103,324$ & \\
MS & $\$ 4.878$ & $\$ 102,431$ & \\
TX & $\$ 4.997$ & $\$ 104,928$ & \\
Avg COP & $\$ 4.964$ & $\$ 104,244$ & \\
\hline
\end{tabular}

${ }^{2}$ Based on an estimate of 21,000 l-gal $(3.8 \mathrm{~L})$ pots per acre $(51,892.1$ pots $/$ ha) $($ Halcomb and Fare, 2009); \$1.00 per acre $=\$ 2.4711$ per ha.

'Based on a 100 -mile $(106.9 \mathrm{~km})$ shipment.

${ }^{x}$ Based on a 150 -d growing season.

wLabor and water costs calculated separately for four locations where experimental results were collected.

"Labor costs based on 5 min of labor per plant multiplied by a factor of 1.25 for nonproductive time, paid at the Adverse Effect Wage Rate plus $7 \%$ for fringe costs and an additional \$2/h for transportation and housing (Hall and Ingram, 2014; U.S. Department of Labor, 2014).

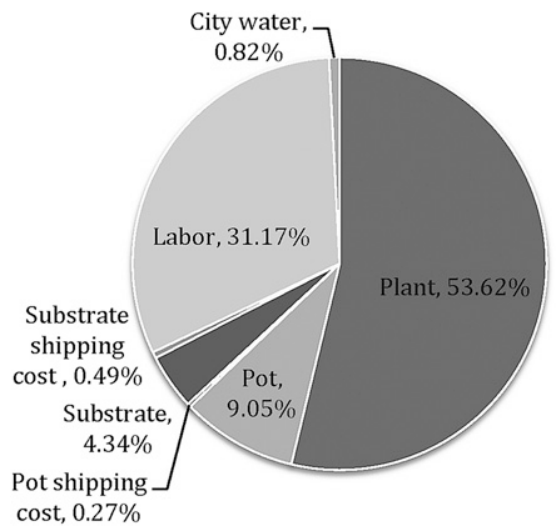

Fig. 1. A percentage breakdown of cost of production (COP) budgets for 'Green Velvet' boxwood grown in plastic containers filled with substrate from 100 miles $(106.9 \mathrm{~km})$ away, irrigated using city water, and tended to by workers paid the Adverse Effect Wage Rate for $150 \mathrm{~d}$ (Hall and Ingram, 2014; U.S. Department of Labor, 2014).

The additional water required for some alternative containers should not affect the profitability of an

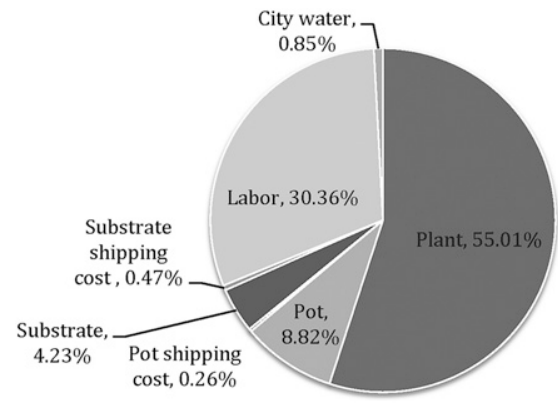

Fig. 2. A percentage breakdown of cost of production (COP) budgets for 'Dark Knight' bluebeard grown in plastic containers filled with substrate from 100 miles $(106.9 \mathrm{~km})$ away, irrigated using city water, and cared for by workers paid the Adverse Effect Wage Rate for $150 \mathrm{~d}$ (Hall and Ingram, 2014; U.S. Department of Labor, 2014).

operation because water cost is insignificant compared with the cost the liner and labor, which make up more than $80 \%$ of the budget of producing plants in plastic containers. More than half of the remaining budget is allocated to the price of the pot, which is 10 times more than the price of irrigation. Furthermore, this is an overestimate of the price of water because it is based on municipal prices. The real cost of water will likely be far less than these numbers in operations that use well or surface water (DeVincentis et al., 2014). When taking into account the cost of drilling wells and pumping the water, irrigation costs are still less than city water.

Although these results show that the cost of water may be insignificant at its current rates, a sensitivity analysis in Table 9 compares irrigation costs based on potential municipal water prices of $\$ 0.005, \$ 0.01$, and \$0.02 per gallon. If water prices were to increase as high as these estimates, $\mathrm{KT}$ and $\mathrm{FB}$ containers would be the most cost-efficient alternatives for growing 'Green Velvet' boxwood. Keratin has the smallest water demand of all containers and could save a grower who was previously using plastic between $\$ 243$ and $\$ 971$ per acre depending on the price of water. Fabric pots could reduce production costs between $\$ 65$ and $\$ 260$ per acre compared with plastic pots depending on the price of water. However, WP and coir pots would increase irrigation costs due to their water demand. Wood pulp pots could increase production costs compared with traditional plastic pots up to $\$ 158 /$ acre for 'Green Velvet' boxwood or up to $\$ 606 /$ acre for growing 'Dark Knight' bluebeard. Coir pots could require an additional $\$ 238 /$ acre to irrigate 'Dark Knight' bluebeard.

\section{Conclusion}

For 'Green Velvet' boxwood, FB is the most cost-effective alternative container that is readily available on the market, but may not be the best alternative when accounting for decreased plant growth. Keratin pots may be a comparable alternative when they appear on the market, but may only save growers money if they are priced less than $\$ 0.04$ per container above the price for plastic pots. Coir pots could be a costeffective alternative for growing 'Dark Knight' bluebeard, assuming they are available at a similar price point as plastic pots. Alternative 
Table 6. Input costs for total cost of production (COP), cost per plant, cost per acre, and proportion of average COP for 'Dark Knight' bluebeard grown in coconut fiber pots in Michigan (MI), Kentucky (KY), Tennessee (TN), Mississippi (MS), and Texas (TX).

\begin{tabular}{|c|c|c|c|}
\hline Component & Cost per plant & Cost per acre & $\begin{array}{l}\text { Proportion of } \\
\text { avg COP (\%) }\end{array}$ \\
\hline Liner plus shipping cost & $\$ 2.496$ & $\$ 52,406$ & 51 \\
\hline Pot & $\$ 1.000$ & $\$ 21,000$ & 20 \\
\hline Pot shipping cost & $\$ 0.012$ & $\$ 250$ & 0.2 \\
\hline Substrate & $\$ 0.192$ & $\$ 4,029$ & 4 \\
\hline Substrate shipping $\cos ^{\mathrm{y}}$ & $\$ 0.021$ & $\$ 451$ & 0.4 \\
\hline City water ${ }^{\mathrm{x}, \mathrm{w}}$ & & & 0.9 \\
\hline MI & $\$ 0.044$ & $\$ 914$ & \\
\hline $\mathrm{KY}$ & $\$ 0.040$ & $\$ 840$ & \\
\hline $\mathrm{TN}$ & $\$ 0.025$ & $\$ 529$ & \\
\hline MS & $\$ 0.041$ & $\$ 870$ & \\
\hline TX & $\$ 0.075$ & $\$ 1,576$ & \\
\hline Labor $^{\mathrm{w}, \mathrm{v}}$ & & & 23 \\
\hline MI & $\$ 1.222$ & $\$ 25,667$ & \\
\hline $\mathrm{KY}$ & $\$ 1.074$ & $\$ 22,562$ & \\
\hline $\mathrm{TN}$ & $\$ 1.074$ & $\$ 22,562$ & \\
\hline MS & $\$ 1.050$ & $\$ 22,048$ & \\
\hline $\mathrm{TX}$ & $\$ 1.155$ & $\$ 24,260$ & \\
\hline Total COP & & & 100 \\
\hline $\mathrm{MI}$ & $\$ 4.987$ & $\$ 104,717$ & \\
\hline $\mathrm{KY}$ & $\$ 4.835$ & $\$ 101,538$ & \\
\hline $\mathrm{TN}$ & $\$ 4.820$ & $\$ 101,226$ & \\
\hline MS & $\$ 4.812$ & $\$ 101,053$ & \\
\hline $\mathrm{TX}$ & $\$ 4.951$ & $\$ 103,972$ & \\
\hline Avg COP & $\$ 4.881$ & $\$ 102,501$ & \\
\hline \multicolumn{4}{|c|}{ 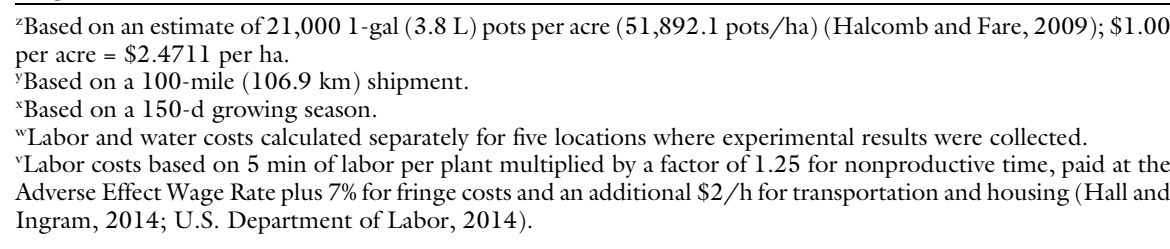 } \\
\hline
\end{tabular}

containers with less water demand than plastic may even save growers money in the future if governmentimposed water restrictions require businesses to use municipal water at high prices.

It is worth noting that this analysis did not include any sales or marketing costs; however, a large audience is willing and eager to pay extra for environmentally conscious products, which could increase sales significantly (Hall et al., 2010; Laroche et al., 2001).

An individual grower must decide his or her level of interest in these benefits because some alternative container options are significantly more expensive than plastic containers. Alternative pots may be valuable inputs because any strategy that can reduce expenses and benefit the environment is a priority for the long-term sustainability of the horticultural industry. Unfortunately, the extent of their adoption in routine nursery production may be limited in the short run because of their current high cost per unit. The cost of alternative containers must likely become more competitive with plastic to make them an acceptable routine choice for commercial growers.

Table 7. Summary of the cost of production (COP), cost per plant, and cost per acre for 'Green Velvet' boxwood and 'Dark Knight' bluebeard grown in black plastic and four alternative containers: wood pulp (WP), fabric (FB), keratin (KT), and coconut fiber (coir) in Michigan (MI), Kentucky (KY), Tennessee (TN), Mississippi (MS), and Texas (TX). Summary includes a sensitivity analysis for the price of $\mathrm{KT}$ and coir pots using $\$ 0.50, \$ 1.00$, and $\$ 2.00$ as suggested prices because these pots are not currently commercially available.

\begin{tabular}{|c|c|c|c|c|c|c|c|}
\hline $\begin{array}{l}\text { 'Green Velvet' } \\
\text { boxwoodz }^{\mathrm{z}}\end{array}$ & $\mathbf{M I}^{\mathrm{y}}$ & KY & MS & TX & & $\begin{array}{l}\text { Avg COP } \\
\text { per plant }^{x} \\
\end{array}$ & $\begin{array}{l}\text { Avg COP } \\
\text { per } \text { acre }^{\mathrm{x}, \mathrm{w}} \\
\end{array}$ \\
\hline Plastic & $\$ 4.526$ & $\$ 4.367$ & $\$ 4.330$ & $\$ 4.450$ & & $\$ 4.418$ & $\$ 92,781$ \\
\hline $\mathrm{FB}$ & $\$ 4.529$ & $\$ 4.391$ & $\$ 4.351$ & $\$ 4.464$ & & $\$ 4.434$ & $\$ 93,107$ \\
\hline $\mathrm{KT} \$ 0.50$ & $\$ 4.562$ & $\$ 4.420$ & $\$ 4.378$ & $\$ 4.497$ & & $\$ 4.464$ & $\$ 93,744$ \\
\hline KT \$1.00 & $\$ 5.062$ & $\$ 4.920$ & $\$ 4.878$ & $\$ 4.997$ & & $\$ 4.964$ & $\$ 104,244$ \\
\hline $\begin{array}{l}\text { 'Dark Knight' } \\
\text { bluebeard }\end{array}$ & MI & KY & TN & MS & TX & $\begin{array}{l}\text { Avg COP } \\
\text { per plant }^{x}\end{array}$ & $\begin{array}{l}\text { Avg COP } \\
\text { per acre } \text { acr,w }^{\mathrm{x}}\end{array}$ \\
\hline Plastic & $\$ 4.655$ & $\$ 4.484$ & $\$ 4.480$ & $\$ 4.461$ & $\$ 4.600$ & $\$ 4.536$ & $\$ 95,257$ \\
\hline WP & $\$ 4.867$ & $\$ 4.716$ & $\$ 4.709$ & $\$ 4.692$ & $\$ 4.836$ & $\$ 4.764$ & $\$ 100,043$ \\
\hline Coir $\$ 0.50$ & $\$ 4.487$ & $\$ 4.335$ & $\$ 4.320$ & $\$ 4.312$ & $\$ 4.451$ & $\$ 4.381$ & $\$ 92,001$ \\
\hline
\end{tabular}

"Green Velvet' boxwood was not grown in TN.

${ }^{y}$ COP budgets reported separately for five locations where experimental results were collected.

'Based on a 100 -mile $(106.9 \mathrm{~km})$ shipment of substrate and a 150 -d growing season.

${ }^{v}$ Based on an estimate of 21,0001 -gal $(3.8 \mathrm{~L})$ pots per acre $(51,892.1$ pots $/$ ha $)($ Halcomb and Fare, 2009$) ; \$ 1.00$ per acre $=\$ 2.4711$ per ha. 
Table 8. Sensitivity analysis for various shipment distances of substrate per acre of production of plants grown in black plastic and four alternative containers: wood pulp (WP), fabric (FB), keratin (KT), and coconut fiber (coir).

\begin{tabular}{|c|c|c|c|c|}
\hline & Plastic and coir ${ }^{z}$ & WP & FB & KT \\
\hline Price of substrate per pot & $\$ 0.192$ & $\$ 0.197$ & $\$ 0.172$ & $\$ 0.151$ \\
\hline Price of substrate per acre & $\$ 4,029$ & $\$ 4,135$ & $\$ 3,605$ & $\$ 3,181$ \\
\hline \multicolumn{5}{|l|}{ Shipment costs per acre ${ }^{y}$} \\
\hline 10 miles $^{x}$ & $\$ 82$ & $\$ 84$ & $\$ 73$ & $\$ 65$ \\
\hline 50 miles & $\$ 246$ & $\$ 253$ & $\$ 220$ & $\$ 194$ \\
\hline 100 miles & $\$ 451$ & $\$ 463$ & $\$ 404$ & $\$ 356$ \\
\hline 200 miles & $\$ 861$ & $\$ 884$ & $\$ 770$ & $\$ 680$ \\
\hline \multicolumn{5}{|c|}{$\begin{array}{l}\text { Difference in total cost per acre with } \\
\text { plastic }^{y}\end{array}$} \\
\hline 10 miles & $\$ 0$ & $-\$ 108$ & $\$ 433$ & $\$ 865$ \\
\hline 50 miles & & $-\$ 112$ & $\$ 450$ & $\$ 900$ \\
\hline 100 miles & & $-\$ 118$ & $\$ 472$ & $\$ 943$ \\
\hline 200 miles & & $-\$ 129$ & $\$ 515$ & $\$ 1,029$ \\
\hline
\end{tabular}

${ }^{2}$ Pots of the same exact size are grouped together.

${ }^{\mathrm{y}}$ Based on an estimate of $21,000 \mathrm{l}$-gal $(3.8 \mathrm{~L})$ pots per acre $(51,892.1$ pots/ha) (Halcomb and Fare, 2009); $\$ 1.00$ per acre $=\$ 2.4711$ per ha

${ }^{\mathrm{x}} 1 \mathrm{mile}=1.6093 \mathrm{~km}$.

Table 9. A sensitivity analysis showing irrigation costs per plant and per acre based on potential municipal water prices for plants grown in black plastic and four alternative containers: wood pulp (WP), fabric (FB), keratin (KT), and coconut fiber (coir).

\begin{tabular}{|c|c|c|c|c|c|}
\hline & \multirow{2}{*}{\multicolumn{2}{|c|}{ 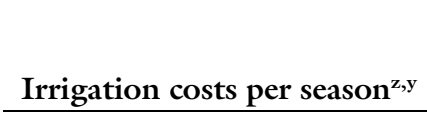 }} & \multicolumn{3}{|c|}{$\begin{array}{l}\text { Difference in price per acre } \\
\text { compared with traditional plastic }\end{array}$} \\
\hline & & & \multirow{2}{*}{$\begin{array}{l}\text { At current } \\
\text { Price }^{\mathrm{y}}\end{array}$} & \multirow{2}{*}{$\begin{array}{l}\text { If prices } \\
\text { doubled }\end{array}$} & \multirow{2}{*}{$\begin{array}{c}\text { If prices } \\
\text { quadrupled }\end{array}$} \\
\hline & per plant & per $\operatorname{acre}^{\mathrm{x}}$ & & & \\
\hline \multicolumn{6}{|c|}{ 'Green Velvet' boxwood } \\
\hline Plastic & $\$ 0.043$ & $\$ 896$ & & & \\
\hline WP & $\$ 0.045$ & $\$ 936$ & $-\$ 40$ & $-\$ 79$ & $-\$ 158$ \\
\hline FB & $\$ 0.040$ & $\$ 831$ & $\$ 65$ & $\$ 130$ & $\$ 260$ \\
\hline KT & $\$ 0.031$ & $\$ 653$ & $\$ 243$ & $\$ 485$ & $\$ 971$ \\
\hline \multicolumn{6}{|c|}{ 'Dark Knight' bluebeard } \\
\hline Plastic & $\$ 0.051$ & $\$ 1,078$ & & & \\
\hline WP & $\$ 0.059$ & $\$ 1,230$ & $-\$ 151$ & $-\$ 303$ & $-\$ 606$ \\
\hline Coir & $\$ 0.054$ & $\$ 1,138$ & $-\$ 60$ & $-\$ 119$ & $-\$ 238$ \\
\hline
\end{tabular}

${ }^{\mathrm{z}}$ Based on daily water use quantities from Wang et al. (2015).

${ }^{\mathrm{y}}$ Based on a water price of $\$ 0.005 / \mathrm{gal}(\$ 0.0013 / \mathrm{L})$.

Based on an estimate of 21,0001 -gal $(3.8 \mathrm{~L})$ pots per acre $(51,892.1$ pots/ha) (Halcomb and Fare, 2009).

\section{Literature cited}

Brumfield, R.G. 2010. Strategies producers in the northeastern United States are using to reduce costs and increase profits in tough economic times. HortTechnology 20:836-843.

Candido, V., V. Miccolis, D. Castronuovo, and C. Manera. 2008. Poinsettia (Euphorbia pulcherrima) cultivation in biodegradable pots: Mechanical and agronomical behaviour of pots and plants traits. Acta Hort. 801:1563-1570.

Circle of Blue. 2014. Water pricing 2014. 30 June 2014. <http://www.circleofblue.org/ waternews/wp-content/uploads/2014/ 05/WaterPricing2014TableInteractive.pdf>.

DeVincentis, A.J., R.G. Brumfield, P. Gottlieb, and J. Johnson. 2014. Cost analysis of recycling water in greenhouses in southern New Jersey. Rutgers, the State University of New Jersey, New Brunswick, Scholars Thesis.

Evans, M.R. and D.L. Hensley. 2004. Plant growth in plastic, peat, and processed poultry feather fiber growing containers. HortScience 39:1012-1014.

Evans, M.R. and D. Karcher. 2004. Properties of plastic, peat, and processed poultry feather fiber growing containers. HortScience 39:1008-1011.

Garthe, J.W. and P.D. Kowal. 1993. Recycling used agricultural plastics. Penn State Fact Sheet C-8. 28 Aug. 2014. <http:// pubs.cas.psu.edu/freepubs/pdfs/ C8.pdf>.

Halcomb, M. and D. Fare. 2009. Conventional container production. 1 Aug. 2014. <http://www.utextension.utk.edu/mtnpi/ handouts/Container\%20Production/ Container_Production_Handout-rev\%20809.pdf>.

Hall, C.R. 2010. Making cents of green industry economics. HortTechnology 20:832-835.

Hall, C.R., B.J. Campbell, B.K. Behe, C. Yue, R.G. Lopez, and J.H. Dennis. 2010. The appeal of biodegradable packaging to floral consumers. HortScience 45:583-591.

Hall, C.R. and D. Ingram. 2014. Production costs of field-grown Cercis canadensis L. 'Forest Pansy' identified during life cycle assessment analysis. HortScience 49:622627.

Hinson, R.A., A. Owings, J. Black, and R. Harkess. 2007. Enterprise budget for plants in plant hardiness zones 8 and 9 . 12 Aug. 2014. <http://www.agecon. msstate.edu/whatwedo/budgets/docs/ 08/Orn08.pdf>.

Khachatryan, H., B. Campbell, C. Hall, B. Behe, C. Yue, and J. Dennis. 2014. The effects of individual environmental concerns on willingness to pay for sustainable plant attributes. HortScience 49:69-75.

Koeser, A.K., S.T. Lovell, A.C. Petri, R.G. Brumfield, and J.R. Stewart. 2014. Biocontainer use in a Petunia $\times$ bybrid greenhouse production system: A cradle-to-gate carbon footprint assessment of secondary impacts. HortScience 49:265-271.

Laroche, M., J. Bergeron, and G. BarbaroForleo. 2001. Targeting consumers who are willing to pay more for environmentally friendly products. J. Consumer Mktg. 18:503-520.

Lopez, R.G. and D.M. Camberato. 2011. Growth and development of 'Eckespoint Classic Red' poinsettia in biodegradable and compostable containers. HortTechnology 21:419-423.

Li, T., G. Bi, G. Niu, S. Nambuthiri, R.L. Geneve, X. Wang, R.T. Fernandez, Y. Sun, and X. Zhao. 2015. Feasibility of using biocontainers in a pot-in-pot system for nursery production of river birch. HortTechnology 25:57-62.

Nambuthiri, S., A. Fulcher, A.K. Koeser, R. Geneve, and G. Niu. 2015. Moving toward sustainability with alternative containers for greenhouse and nursery crop production: A review and research update. HortTechnology 25:8-16.

Nambuthiri, S. and D. Ingram. 2014. Evaluation of plantable containers for groundcover plant production and their establishment in a landscape. HortTechnology 24:48-52. 
U.S. Department of Labor. 2014. Adverse effect wage rates 2014. 15 July 2014. <http://www.foreignlaborcert.doleta.gov/ adverse.cfm>.

Wang, X. 2013. Irrigation management and alternative containers for more sustainable nursery production. Michigan State Univ., East Lansing, MS Thesis.

Wang, X., R.T. Fernandez, B.M. Cregg, R. Auras, A. Fulcher, D.R. Cochran, G. Niu,
Y. Sun, G. Bi, S. Nambuthiri, and R.L. Geneve. 2015. Multistate evaluation of plant growth and water use in plastic containers and alternative nursery containers. HortTechnology 25:42-49.

Yue, C., J.H. Dennis, B.K. Behe, C.R. Hall, B.L. Campbell, and R.G. Lopez. 2011. Investigating consumer preference for organic, local, or sustainable plants. HortScience 46:610-615.
Yue, C., C.R. Hall, B.K. Behe, B.L. Campbell, and J.H. Dennis. 2010. Are consumers willing to pay more for biodegradable containers than for plastic ones? Evidence from hypothetical conjoint analysis and nonhypothetical experimental auctions. J. Agr. Appl. Econ. 42:757-772. 